\author{
A. Kausar* \\ National University of Sciences and Technology, Islamabad, Pakistan \\ *asheesgreat@yahoo.com
}

\title{
STRUCTURE AND PROPERTIES OF POLYACRYLONITRILE/ POLYSTYRENE AND CARBON NANOPARTICLE-BASED NANOCOMPOSITE FOAMS
}

\begin{abstract}
In this study, novel polyacrylonitrile/polystyrene (PAN/PS) blend has been prepared and reinforced with carbon nanoparticle to form polyacrylonitrile/polystyrene/carbon nanoparticle (PAN/PS/CNP) nanocomposite foam. Acidfunctional carbon nanoparticle (0.1-3 wt.\%) was used as nano-reinforcement for PAN/PS blend matrix. 2'azobisisobutyronitrile was employed as foaming agent. The PAN/PS/CNP nanocomposite foams have been tested for structure, morphology, mechanical properties, thermal stability, non-flammability, water uptake, and toxic ion removal. Field-emission scanning electron microscopy and transmission electron microscopy exposed unique nanocellular morphology owing to physical interaction between the matrix and functional CNP. PAN/PS/CNP 0.1 Foam with $0.1 \mathrm{wt} . \%$ nanofiller had compression strength, modulus, and foam density of $41.8 \mathrm{MPa}, 22.3 \mathrm{GPa}$, and 0.9 $\mathrm{mgcm}^{-3}$, respectively. Nanofiller loading of $3 \mathrm{wt} . \%$ (PAN/PS/CNP 3 Foam) considerably enhanced the compression strength, modulus, and foam density as $68.2 \mathrm{MPa}, 37.7 \mathrm{GPa}$, and $1.9 \mathrm{mgcm}^{-3}$, respectively. CNP reinforcement also enhanced the initial weight loss and maximum decomposition temperature of PAN/PS/CNP 3 Foam to 541 and 574 ${ }^{\circ} \mathrm{C}$, relative to neat foam $\left(\mathrm{T}_{0}=411{ }^{\circ} \mathrm{C} ; \mathrm{T}_{10}=459{ }^{\circ} \mathrm{C}\right)$. Nanocomposite foams have also shown excellent flame retardancy as V-0 rating and high char yield of up to $57 \%$ were attained. Due to hydrophilic nature of functional carbon nanoparticle, water absorption capacity of $3 \mathrm{wt} . \%$ nanocomposite foam was $30 \%$ higher than that of pristine foam. Moreover, novel foams were also tested for the removal of toxic $\mathrm{Pb}^{2+}$ ions. PAN/PS/CNP 3 Foam has shown much higher ion removal capacity $(166 \mathrm{mg} / \mathrm{g})$ and efficiency $(99 \%)$ than that of PAN/PS foam having removal capacity and efficiency of $90 \mathrm{mg} / \mathrm{g}$ and $45 \%$, respectively.
\end{abstract}

Keywords: polyacrylonitrile; polystyrene $\mathrm{CNP}$; foam; $\mathrm{Pb}^{2+}$ ions

\section{INTRODUCTION}

Polyacrylonitrile (PAN) is an acrylic thermoplastic polymer having range of useful properties such as high strength, modulus, and thermal stability [1]. PAN occur as film, fiber, foam, and other useful polymeric forms [2, 3]. An important property of PAN is associated with the absorption of toxic metal ions [4]. Polystyrene (PS) is also a synthetic thermoplastic polymer $[5,6]$. It is transparent, hard, stiff, and one of the most widely used plastic. It is an economical polymer having scale of production of several million tons per year. Blending of polyacrylonitrile 
and polystyrene is known in literature [7, 8]. PAN/PS blends have shown fine dispersion, thermal stability, and superior physical properties. PAN and carbon nanomaterial-based composite have been used for high performance industrial applications such as absorbent, electrode, gas storage media, catalyst support, etc. $[9,10]$. Correspondingly, polystyrene reinforced with graphene and carbon nanotube possess high electrical conductivity, thermal stability, and mechanical strength to be employed in technical applications [11, 12]. Tribological behavior of polystyreneacrylonitrile mixed with carbon nanotube has been reported [13, 14]. However, not much literature is available regarding the PAN/PS blends with filled carbonaceous nanofillers. Carbon nanoparticle (CNP) is a unique and less studied form of carbon nanomaterials [15]. CNP is a zero-dimensional nanocarbon having diameter $<10 \mathrm{~nm}$. It consists of multilayer fullerene-like structure [16]. CNP is capable of substituting other nanocarbon nanofillers such as carbon nanotube, graphene, graphite, owing to range of exceptional structural and physical properties. CNP has been reinforced in polystyrene, polyamide, polyaniline, polypyrrole, and polythiophene matrices [17]. CNP-based materials have found applications in batteries, supercapacitor, solar cell, and biomedical fields. To the best of knowledge, CNP nanofiller has not been reinforced in PAN or PAN blends. In this study, acid functional carbon nanoparticle has been reinforced in novel polyacrylonitrile/polystyrene blend to form polyacrylonitrile/polystyrene/carbon nanoparticle (PAN/PS/CNP) nanocomposite foams. PAN foam has been reported for various technical applications such as solar cell, fuel cell, Li-ion battery, sensor, biomedical, and removal of environmental toxicity [18-20]. However, PAN/PS/CNP nanocomposite foams is not reported before. This study reports on structure, morphology, compression mechanical properties, thermal stability, non-flammability, water uptake, and toxic metal ion removal of novel PAN/PS/CNP nanocomposite foams.

\section{EXPERIMENTAL}

\section{Chemicals}

Carbon nanoparticle (CNP, diameter 70-100 nm), polyacrylonitrile (PAN, average $\mathrm{M}_{\mathrm{w}} \sim 1.5 \times 10^{5}$ ), polystyrene (PS, $\mathrm{M}_{\mathrm{w}} 35 \times 10^{3}$ ), 2'-azobisisobutyronitrile (AIBN, 98\%), and N,Ndimethylformamide (DMF, 99\%) were supplied by Aldrich.

\section{Instrumentation}

Fourier transform infrared (FTIR) spectra were recorded using Excalibur Series FTIR Spectrometer, Model No. FTSW 300 MX manufactured by BIO-RAD. The compression strength and modulus were measured using universal electronic tensile machine (Shimadzu, Japan). The compressive rate was $2 \mathrm{~mm} / \mathrm{min}$ according to ASTM D 1621-94. Morphology was investigated by FEI Nova 230 field emission scanning electron microscope (FE-SEM). The samples were cryogenically fractured in liquid nitrogen before analysis. Transmission electron microscopy (TEM) was performed with LEO 912 Omega instrument at $120 \mathrm{kV}$. The ultrathin sections were prepared using an Ultracut E ultramicrotome diamond knife. Thermal stability of materials was determined by NETZSCH thermogravimetric analyzer (TGA), model no. TG 209 F3, using 1-5 mg of the sample in $\mathrm{Al}_{2} \mathrm{O}_{3}$ crucible. The heating rate of $10{ }^{\circ} \mathrm{C} / \mathrm{min}$ was maintained up to $800{ }^{\circ} \mathrm{C}$ under nitrogen flow rate of $30 \mathrm{~mL} / \mathrm{min}$. UL-94 test was executed $\left(100 \times 10 \times 5 \mathrm{~mm}^{3}\right)$ according to 
ASTM D635-77. For moisture absorption, the test samples were placed in deionized water (24, $48,72 \& 96$ h) after dry weighing. The specimens were removed from water and again weighed. The increase in mass was calculated for assessment of water absorption percentage. The change of $\mathrm{Pb}^{2+}$ ion concentration in aqueous solution was determined using atomic adsorption spectrophotometer (AAS, SHIMADZU AA-6701F). The time-dependent metal ion removal capacity $\left(\mathrm{q}_{\mathrm{t}}\right)$ of $\mathrm{Pb}^{2+}$ ions was studied. The stock solution of $\mathrm{Pb}^{2+}$ ions was prepared by dissolving metal acetate salt in deionized water. Initial $\mathrm{Pb}^{2+}$ concentration of $\mathrm{Pb}^{2+}$ ion was $5 \mathrm{mmol}$ metal ion/L $(1000 \mathrm{mg} / \mathrm{L})$ at $\mathrm{pH} 3$. The $\mathrm{pH}$ was adjusted using $0.1 \mathrm{M} \mathrm{NaOH}$ solution. The foam sample was placed in aqueous solution of $100 \mathrm{~mL}$ with desired initial $\mathrm{Pb}^{2+}$ ion concentration. All the experiments were carried out at room temperature.

\section{Functionalization of carbon nanoparticle (CNP)}

In $100 \mathrm{~mL}$ THF, $1 \mathrm{~g}$ carbon nanoparticle was dispersed. Then, $50 \mathrm{~mL}$ conc. $\mathrm{HNO}_{3}$ was added drop wise to the mixture with continuous stirring of $2 \mathrm{~h}\left(70^{\circ} \mathrm{C}\right)$. The product was washed with excess amount of distilled water to obtain the functional nanofiller. FTIR $(\mathrm{KBr})$ spectrum reveal peaks at $3405 \mathrm{~cm}^{-1}$ (O-H stretching vibration), $1635 \mathrm{~cm}^{-1}$ (O-H bending vibration), $1721 \mathrm{~cm}^{-1}$ ( $\mathrm{C}=\mathrm{O}$ stretching vibration), $2890 \mathrm{~cm}^{-1}\left(\mathrm{C}-\mathrm{H}\right.$ stretching vibration), and $1270 \mathrm{~cm}^{-1}(\mathrm{C}-\mathrm{O})$ [21] .

\section{Preparation of polyacrylonitrile/polystyrene (PAN/PS) blend}

$0.9 \mathrm{~g}$ polyacrylonitrile was dissolved in $20 \mathrm{~mL}$ DMF with continuous stirring of $24 \mathrm{~h}$ at 60 ${ }^{\circ} \mathrm{C}$. 0.1g PS was also dissolved in $0.3 \mathrm{~mL}$ DMF separately. For blend formation, PAN and PS solutions were mixed and refluxed at $120^{\circ} \mathrm{C}$ for $3 \mathrm{~h}$. The mixture was caste in glass Petri dishes at $80{ }^{\circ} \mathrm{C}$ for $24 \mathrm{~h}$ [22]. FTIR spectrum show peaks around 3010 (aromatic $\mathrm{C}-\mathrm{H}$ stretching vibration), $2911 \mathrm{~cm}^{-1}$ (aliphatic $\mathrm{C}-\mathrm{H}$ stretching vibration), $2231 \mathrm{~cm}^{-1}$ ( $-\mathrm{C} \equiv \mathrm{N}$ stretching vibration), $1450 \mathrm{~cm}^{-1}$ (C-N stretching vibration), and $1551,1647 \mathrm{~cm}^{-1}(\mathrm{C}=\mathrm{C}$ stretching vibration).

\section{Preparation of polyacrylonitrile/polystyrene/carbon nanoparticle (PAN/PS/CNP) nanocomposite}

The PAN/PS blend solution was prepared according to the procedure mentioned in above Section 2.4. After refluxing the blend mixture at $120^{\circ} \mathrm{C}$ for $3 \mathrm{~h}$, CNP nanofiller (0.1-3 wt.\%) was added to the mixture. The reaction mixture was futher refluxed for $2 \mathrm{~h}$ at $120^{\circ} \mathrm{C}$. The films were caste in Petri dishes at $80^{\circ} \mathrm{C}$ for $24 \mathrm{~h}$ under vacuum (Fig. 1).

\section{Preparation of PAN/PS/CNP Foam}

Initially, PAN/PS/CNP nanocomposite (0.1-3 wt.\%) was prepared as mentioned in above Section 2.5. Then solution of $3 \mathrm{wt} . \%$ foaming agent AIBN was prepared in $1 \mathrm{~mL}$ DMF and added to the nanocomposite mixture. The mixture was refluxed at $120^{\circ} \mathrm{C}$ for $1 \mathrm{~h}$. The reaction mixture was poured in Petri dish and allowed to dry at $80^{\circ} \mathrm{C}$ for $12 \mathrm{~h}$. The dried nanocomposite films were finally hot pressed. During pressing, foaming agent was decomposed to form foam structures [23]. FTIR peaks identified as $3231 \mathrm{~cm}^{-1}$ (O-H stretch), $3001 \mathrm{~cm}^{-1}$ (aromatic C-H stretch), $2906 \mathrm{~cm}^{-1}$ (aliphatic $\mathrm{C}-\mathrm{H}$ stretching vibration), $2229 \mathrm{~cm}^{-1}\left(-\mathrm{C} \equiv \mathrm{N}\right.$ stretching vibration), $1441 \mathrm{~cm}^{-1}(\mathrm{C}-\mathrm{N}$ stretching vibration), and $1530,1610 \mathrm{~cm}^{-1}(\mathrm{C}=\mathrm{C}$ stretching vibration $)$. 


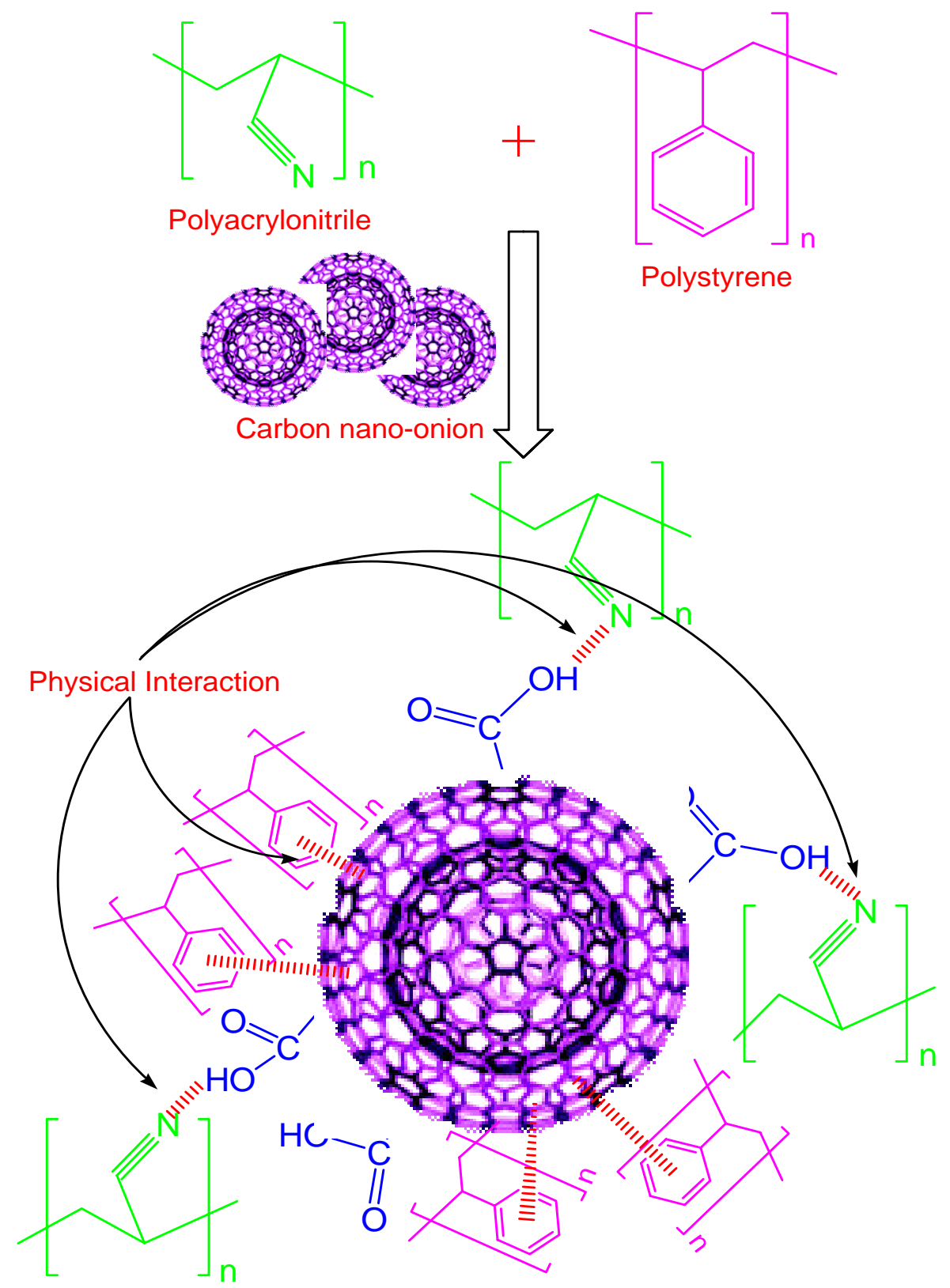

Fig. 1. Schematic for the formation of PAN/PS and CNP nanocomposite

\section{RESULTS AND DISCUSSION}

\section{FTIR analysis}

Fig. 2 reveals FTIR spectral features of PAN/PS and PAN/PS/CNP 3 Foam. The nitrile group of PAN backbone appeared at $1450 \mathrm{~cm}^{-1}$. The $-\mathrm{C} \equiv \mathrm{N}$ peak at $2231 \mathrm{~cm}^{-1}$ also show the presence of PAN structure (Fig. 2A). The PAN/PS also depicts aromatic C-H stretching vibration at $3010 \mathrm{~cm}^{-1}$ due to polystyrene rings in the spectrum. The peaks at 1551 and $1647 \mathrm{~cm}^{-1}$ were 
attributed to aromatic $\mathrm{C}=\mathrm{C}$ stretching vibrations. The aliphatic protons also appeared at $2911 \mathrm{~cm}^{-1}$. Fig. 2B shows the FTIR spectrum of nanocomposite foam. After the incorporation of functional CNP nanofiller, the hydroxyl $\mathrm{O}-\mathrm{H}$ group was observed at $3231 \mathrm{~cm}^{-1}$. Moreover, $-\mathrm{C} \equiv \mathrm{N}$ group of PAN was found at lower wavenumber $2229 \mathrm{~cm}^{-1}$ due to hydrogen bonding interaction with the hydroxyl group of functional CNP. The $\mathrm{C}-\mathrm{N}$ stretching vibration was also found at lower position $\left(1441 \mathrm{~cm}^{-1}\right)$. Due to ring stacking interaction, aromatic protons $\left(3001 \mathrm{~cm}^{-1}\right)$ and $\mathrm{C}=\mathrm{C}\left(1530,1610 \mathrm{~cm}^{-1}\right)$ stretching vibrations were also shifted to lower wavenumber. However, separate carbonyl peak $\left(1700 \mathrm{~cm}^{-1}\right)$ cannot be observed in the spectrum may be due to interaction between the matrix and nanofiller and possible overlapping with aromatic $\mathrm{C}=\mathrm{C}$ stretching vibration. Consequently, spectral data offered sufficient evidences regarding the incorporation of carbon nanoparticle in polymer framework and also interaction between the matrix-nanofiller.

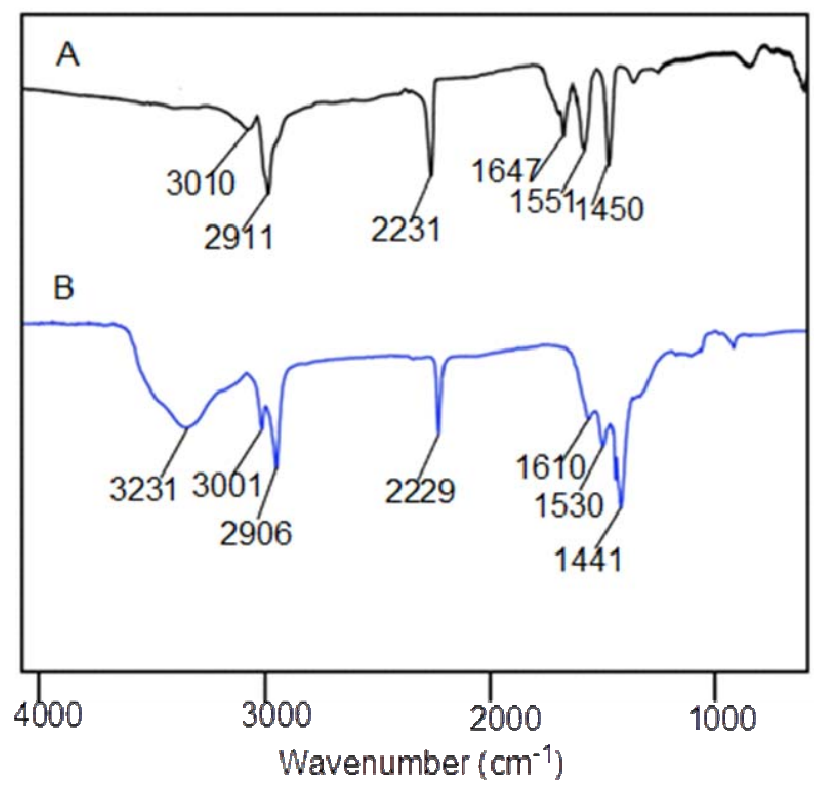

Fig. 2. FTIR spectra of (A) PAN/PS and (B) PAN/PS/CNP 3 Foam

\section{Microstructure study}

Field emission scanning electron microscopy (FESEM) was used to explore the microstructure of polyacrylonitrile/polystyrene blend and PAN/PS/CNP nanocomposite. The morphology of PAN/PS was found spongy in nature with small pores (Fig. 3A). Unsurprisingly, neat polymer blend foam had ill-defined cell structure. Addition of $0.1 \mathrm{wt} . \%$ nanofiller not caused any substantial change in the morphology of PAN/PS blend (Fig. 3B). However, 0.3 wt.\% nanofiller addition instigated visible change in morphology relative to the neat blend (Fig. $3 \mathrm{C}$ ). Morphology of PAN/PS/CNP 1 Foam seems to have spongy, branched, and porous morphology (Fig. 3D). Additional inclusion of nanofiller up to $3 \mathrm{wt} . \%$ also depicts same branched spongy morphology (Fig. 3E). 


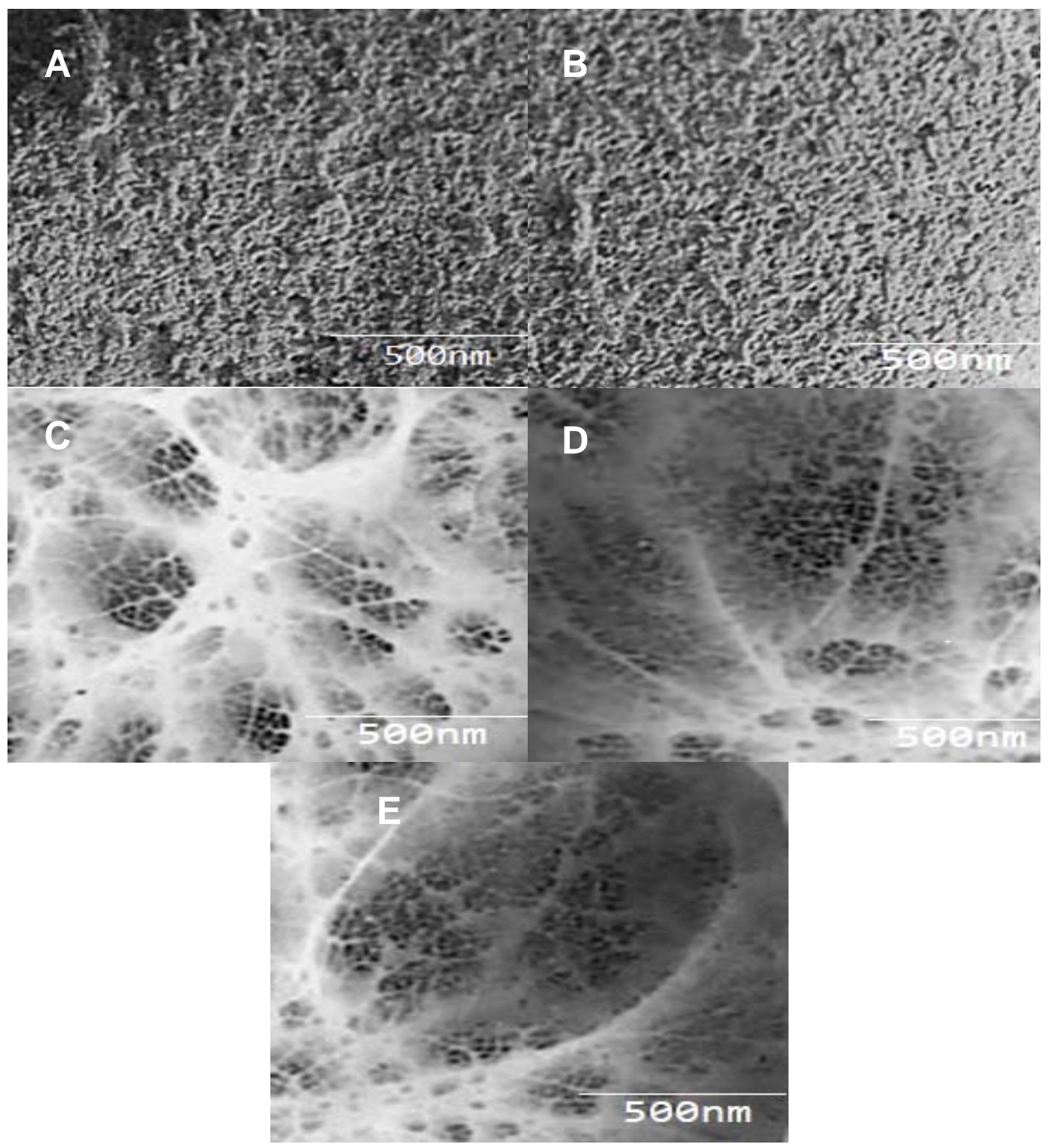

Fig. 3. FESEM micrographs of (A) PAN/PS Foam; (B) PAN/PS/CNP 0.1 Foam; (C) PAN/PS/CNP 0.3 Foam; (D) PAN/PS/CNP 1 Foam; and (E) PAN/PS/CNP 3 Foam

The unique morphology was attributed to physical interaction between the matrix and nanofiller and synergetic effect in the blended polymers and functional CNP leading to the formation of homogenously aligned framework [24]. Nevertheless, the cell structure of foams was not evident in the FESEM micrographs. TEM micrographs of PAN/PS Foam (Fig. 4A), PAN/PS/CNP 0.3 Foam (Fig. 4B), and PAN/PS/CNP 3 Foam (Fig. 4C) show exclusive nanocellular morphology. The cells were square shaped and homogeneously dispersed in the foam matrix. Perfectly aligned and uniform cell structure was observed in TEM micrographs. 


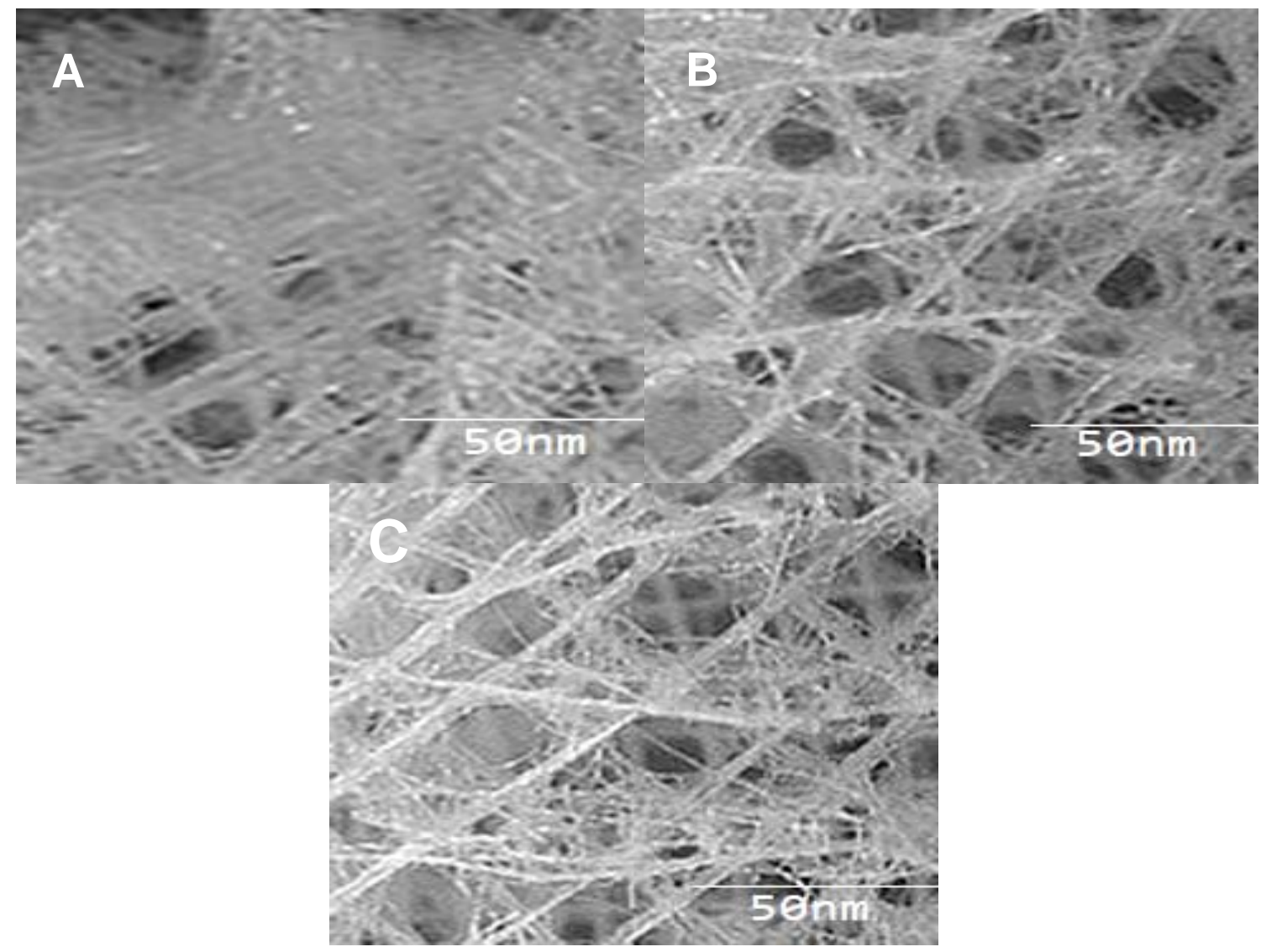

Fig. 4. TEM micrographs of (A) PAN/PS Foam; (B) PAN/PS/CNP 0.3 Foam; and (C) PAN/PS/CNP 3 Foam

\section{Compression strength and modulus of PAN/PS Foam and PAN/PS/CNP Foam}

Table 1 shows compression strength and compression modulus of pristine PAN/PS blend and PAN/PS/CNP nanocomposite foam. Fig. 5 and Fig. 6 show increase in compression mechanical properties with CNP addition. Neat PAN/PS foam sample possess compression strength and modulus of $33.5 \mathrm{MPa}$ and $5.5 \mathrm{GPa}$, respectively. PAN/PS/CNP 0.1 Foam with 0.1 wt.\% nanofiller yield compression strength of $41.8 \mathrm{MPa}$. Inclusion of $0.3 \mathrm{wt} . \%$ nanofiller enhanced the compression strength upto 55.2 MPa. Further addition of 0.6 and $1 \mathrm{wt} . \%$ nanofiller enhanced the strength to 57.7 and 62.1 MPa. PAN/PS/CNP 3 Foam showed highest compression strength of $68.2 \mathrm{MPa}$. In this way, there was $51 \%$ increase in the compression strength of $3 \mathrm{wt} . \%$ foam compared with the neat polymer foam. The effect of nanocarbon nanofillers has already been observed for enhanced strength properties $[25,26]$. Similar increasing trend was observed for the compression modulus of nanocomposite foams. Compression modulus of $0.1 \mathrm{wt} . \%$ loaded foam was $22.3 \mathrm{GPa}$. Reinforcement from $0.3-3$ wt. $\%$ increased the modulus values from 29.6 to 37.7 GPa. There was $85 \%$ increment in the compression modulus of PAN/PS/CNP 0.3 Foam relative to the neat blend foam. Increase in mechanical properties of nanocomposite foams with nanocarbon addition follows the literature trend observed [27, 28]. Carbon nanoparticles were found advantageous to enhance the mechanical properties of novel foams relative to graphene and carbon nanotube-coated polymer foams. 
Table 1. Mechanical properties and density of PAN/PS Foam and PAN/PS/CNP Foam

\begin{tabular}{lccc}
\hline \multicolumn{1}{c}{ Sample } & $\begin{array}{c}\text { Compression } \\
\text { Strength }(\mathrm{MPa})\end{array}$ & $\begin{array}{c}\text { Compression } \\
\text { Modulus } \\
(\mathrm{GPa})\end{array}$ & $\begin{array}{c}\text { Density } \\
\left(\mathrm{mgcm}^{-3}\right)\end{array}$ \\
\hline PAN/PS & 33.5 & 5.5 & 0.5 \\
PAN/PS/CNP 0.1 Foam & 41.8 & 22.3 & 0.9 \\
PAN/PS/CNP 0.3 Foam & 55.2 & 29.6 & 1.1 \\
PAN/PS/CNP 0.6 Foam & 57.7 & 30.1 & 1.4 \\
PAN/PS/CNP 1 Foam & 62.1 & 33.3 & 1.7 \\
PAN/PS/CNP 3 Foam & 68.2 & 37.7 & 1.9 \\
\hline
\end{tabular}

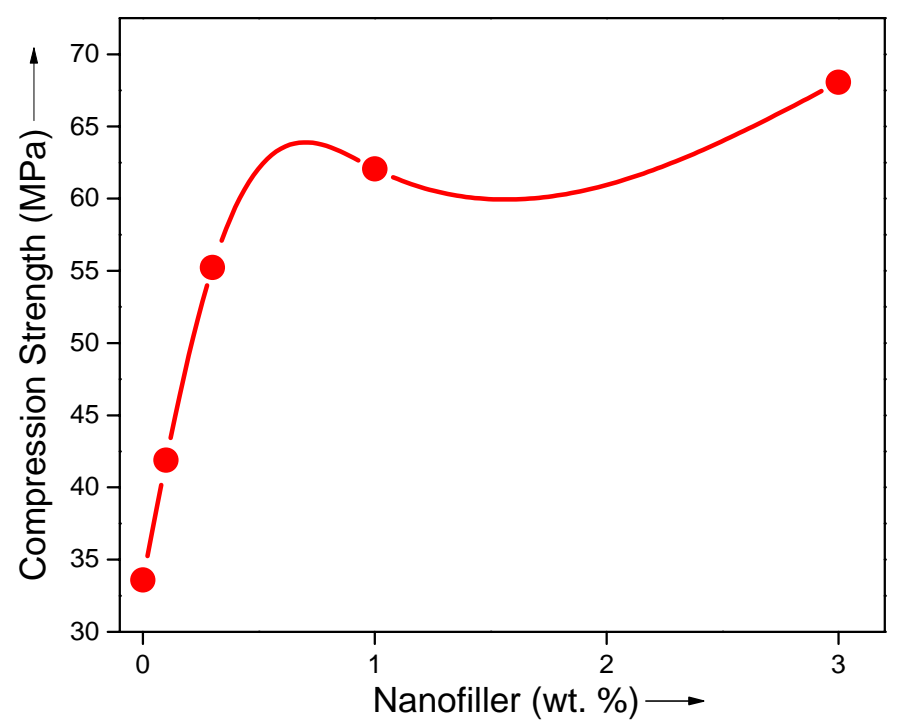

Fig. 5. Compression strength of PAN/PS Foam and PAN/PS/CNP Foam

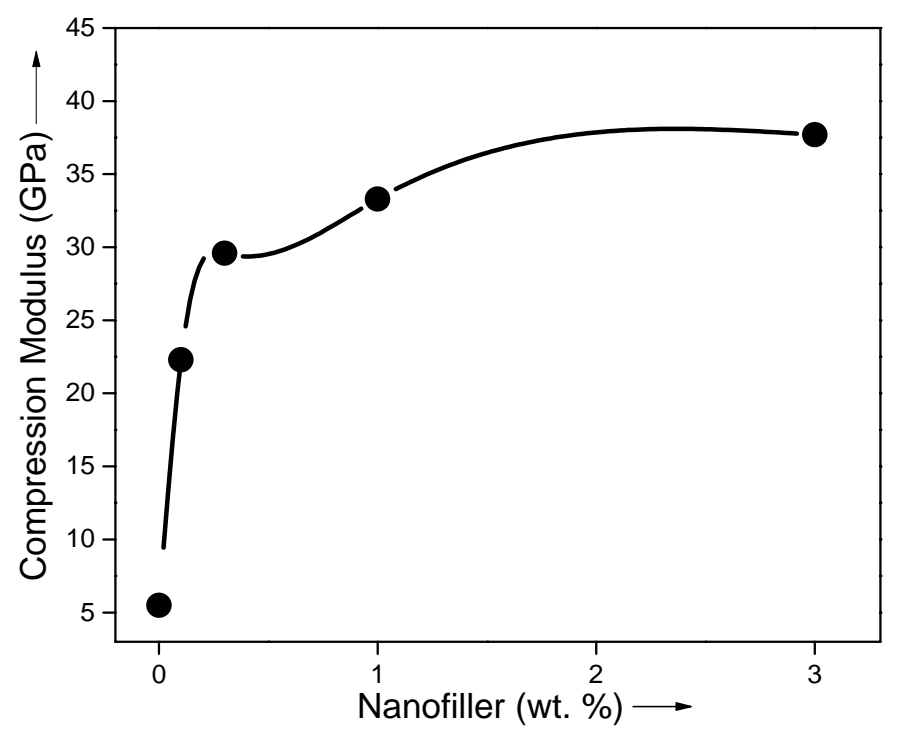

Fig. 6. Compression modulus of PAN/PS Foam and PAN/PS/CNP Foam 


\section{Thermogravimetric and non-flammability measurements}

Table 2 shows thermogravimetric analysis of blend and PAN/PS/CNP nanocomposite foams. The thermograms are presented in Fig. 7. The PAN/PS blend had initial weight loss $\left(\mathrm{T}_{0}\right), 10 \%$ degradation temperature $\left(T_{10}\right)$, and maximum decomposition temperature $\left(T_{\max }\right)$ of 411,418 , and $459^{\circ} \mathrm{C}$, respectively. Thermal properties of neat blend were found superior relative to neat PS or PAN owing to blending effect of the two polymers. Incorporation of $0.1 \mathrm{wt} \%$ nanofiller enhanced the $\mathrm{T}_{0}, \mathrm{~T}_{10}$, and $\mathrm{T}_{\max }$ to 501,523 , and $555^{\circ} \mathrm{C}$, respectively. The $0.3 \mathrm{wt} . \%$ reinforcement further enhanced the $\mathrm{T}_{0}, \mathrm{~T}_{10}$, and $\mathrm{T}_{\max }$ to 511,530 , and $559^{\circ} \mathrm{C}$. The thermal properties were raised constantly with CNP loading and attained $\mathrm{T}_{0}$ of $529{ }^{\circ} \mathrm{C}, \mathrm{T}_{10}$ of $544{ }^{\circ} \mathrm{C}$ and $\mathrm{T}_{\max }$ of $568{ }^{\circ} \mathrm{C}$ for PAN/PS/CNP 1 Foam. Greatest improvement in thermal properties were achieved with $3 \mathrm{wt} . \%$ nanofiller loading $\left(\mathrm{T}_{0}=541, \mathrm{~T}_{10}=559\right.$, and $\left.\mathrm{T}_{\max }=574\right)$. Consequently, initial and maximum weight loss values were improved by $24 \%$ and $20 \%$ respectively, relative to neat blend foam. It seems that the nanofiller loading developed physical interaction with the foam matrix and led to unique microcellular morphology. The stable matrix-nanofiller framework in turn improved the thermal stability and mechanical strength of PAN/PS/CNP foams. Table 2 also illustrates nonflammability data of the samples. According to UL-94 test, V-0 rating was obtained for all the nanocomposite foams. Carbon nanoparticle addition was found to constantly increase the char yield of the nanocomposite. According to literature, high char yield of nanocomposite foams (45$57 \%$ ) points to non-flammability capability of the samples [29-31]. Inclusion of $3 \mathrm{wt} \%$ of nanofiller considerably enhanced the char yield of neat PAN/PS blend (22\%) up to $57 \%$. The enhanced char yield can be attributed to inherent flame retardancy of carbon nanoparticle and formation of a stable matrix-nanofiller foam network resilient to heat. Thus, the nanocomposite structure and non-flammability behavior of CNP nanofiller supported the flame retardancy of PAN/PS/CNP foams $[23,32]$. Compared with the literature polyamide and graphene systems, novel PAN and carbon nanoparticles have shown comparable thermal and non-flammabolity properties [31]. Thus, the effect of carbon nanoparticle has been identified in improving the heat constancy of the materials.

Table 2. Thermal analyses and flammability data of PAN/PS Foam and PAN/PS/CNP Foam

\begin{tabular}{lccccc}
\hline \multicolumn{1}{c}{ Sample } & $\mathrm{T}_{0}\left({ }^{\circ} \mathrm{C}\right)$ & $\mathrm{T}_{10}\left({ }^{\circ} \mathrm{C}\right)$ & $\mathrm{T}_{\max }\left({ }^{\circ} \mathrm{C}\right)$ & $\begin{array}{c}\text { Char yield } \\
(\%)\end{array}$ & UL-94 \\
\hline PAN & 265 & 276 & 399 & 44 & - \\
PS & 319 & 370 & 390 & 10 & - \\
PAN/PS & 411 & 418 & 459 & 22 & $\mathrm{~V}-0$ \\
PAN/PS/CNP 0.1 Foam & 501 & 523 & 555 & 45 & $\mathrm{~V}-0$ \\
PAN/PS/CNP 0.3 Foam & 511 & 530 & 559 & 47 & $\mathrm{~V}-0$ \\
PAN/PS/CNP 0.6 Foam & 517 & 539 & 564 & 49 & $\mathrm{~V}-0$ \\
PAN/PS/CNP 1 Foam & 529 & 544 & 568 & 50 & $\mathrm{~V}-0$ \\
PAN/PS/CNP 3 Foam & 541 & 559 & 574 & 57 & $\mathrm{~V}-0$ \\
\hline
\end{tabular}




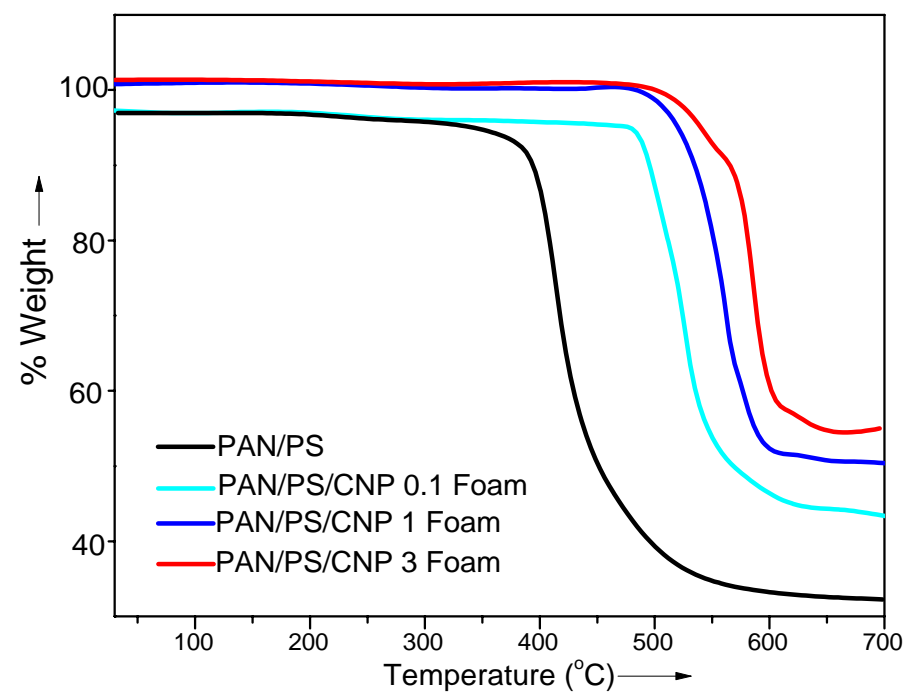

Fig. 7. TGA curves of PAN/PS and PAN/PS/CNP nanocomposite foam at $10^{\circ} \mathrm{C} / \mathrm{min}$ (N2)

\section{Moisture absorption analysis}

Table 3 shows moisture absorption test performed using a simple method. First, the initial dry weight of samples was measured. Then, the samples were immersed in de-ionized water for the desired period of time $(24,48,72,96 \mathrm{~h})$. The study was carried out at room temperature (27 $\left.{ }^{\circ} \mathrm{C}\right)$. After the completion of test period, foam specimens were taken out from water and dried. The dried samples were weighed to examine the weight difference and \% water absorption (Eq. $1)$.

$$
\text { Increase in weight }(\%)=(\mathrm{W}-\mathrm{D}) / \mathrm{D} \times 100
$$

Where $\mathrm{W}=$ wet weight and $\mathrm{D}=$ dry weight. After $24 \mathrm{~h}$, neat foam, PAN/PS/CNP 0.1 Foam, PAN/PS/CNP 0.3 Foam, PAN/PS/CNP 1 Foam, and PAN/PS/CNP 3 Foam showed water absorption of $7.31,9.31,12.1,18.3$, and $20.6 \%$, respectively. Increase in soaking time period considerably enhanced the moisture absorption by foams. The overall trend obtained is shown in Fig. 8. Maximum moisture absorption was observed after $96 \mathrm{~h}$ as 53.8, 62.3, 69.9, 72.3, and $77.4 \%$ respectively for neat foam, PAN/PS/CNP 0.1 Foam, PAN/PS/CNP 0.3 Foam, PAN/PS/CNP 1 Foam, and PAN/PS/CNP 3 Foam. Thus, higher water absorption was observed with 3 wt.\% nanofiller loading $(96 \mathrm{~h})$ in the foam sample i.e. 30\% higher than the pristine foam. Increase in water absorption with nanofiller loading can be attributed to the presence of hydrophilic nature of acid functional CNP in the foam structure [33-35]. The Young's contact angle of neat blend and nanocomposite was also measured to perceive the water absorption trend. The contact angle of the blend was low $\left(80^{\circ}\right)$. Varying the weight fraction of nanofiller blended with polymers systematically increased the contact angle to about $120^{\circ}$. The increase in contact angle with nanofiller loading also points to hydrophilic nature of functional CNP. 
Table 3. \%Water absorption and Pb2+ ion removal efficiency of PAN/PS Foam and PAN/PS/CNP Foam

\begin{tabular}{lccccc}
\hline \multirow{2}{*}{ Time $(\mathrm{h})$} & \multicolumn{5}{c}{ \% Water absorption } \\
\cline { 2 - 6 } & $\begin{array}{c}\text { PAN/PS } \\
\text { Foam }\end{array}$ & $\begin{array}{c}\text { PAN/PS/CNP } \\
0.1 \text { Foam }\end{array}$ & $\begin{array}{c}\text { PAN/PS/CNP } \\
0.3 \text { Foam }\end{array}$ & $\begin{array}{c}\text { PAN/PS/CNP } \\
\text { 1 Foam }\end{array}$ & $\begin{array}{c}\text { PAN/PS/CNP } \\
\text { 3 Foam }\end{array}$ \\
\hline \multicolumn{1}{c}{7.31} & 9.31 & 12.1 & 18.3 & 20.6 \\
48 & 17.4 & 20.8 & 26.1 & 29.3 & 39.1 \\
72 & 38.1 & 45.3 & 49.1 & 50.7 & 59.9 \\
96 & 53.8 & 62.3 & 69.9 & 72.3 & 77.4 \\
Metal ion removal & 90 & 141 & 149 & 153 & 166 \\
capacity (mg/g) & & & & & 92 \\
Removal & 45 & 77 & 90 & 110 & 120 \\
efficiency (\%) & 80 & 83 & 98 & & 92 \\
Contact angle $\left({ }^{\circ}\right)$ & & &
\end{tabular}

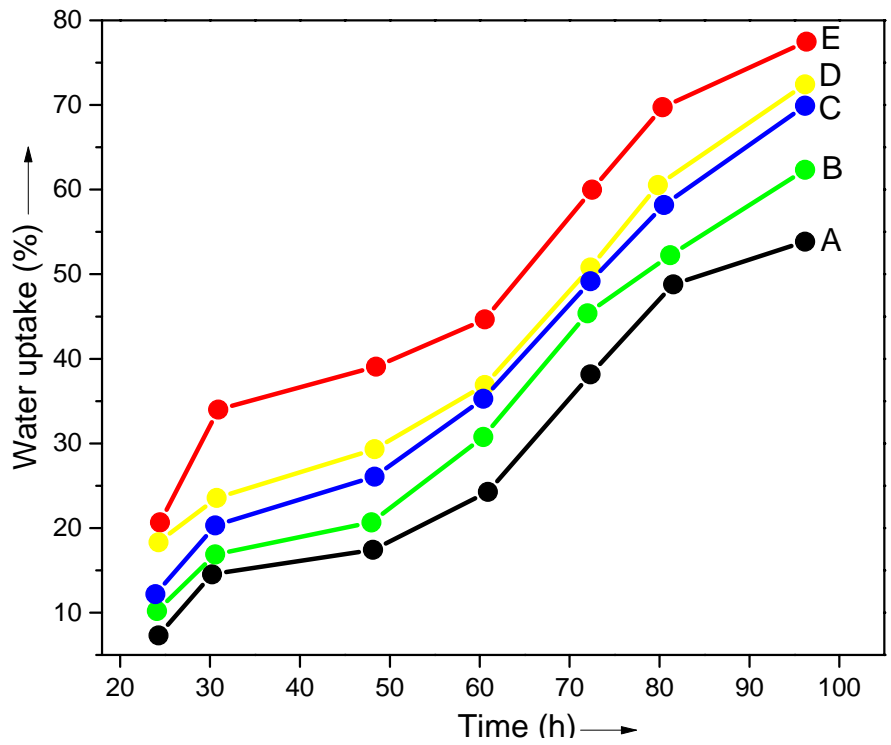

Fig. 8. Water uptake characteristics of (A) PAN/PS Foam; (B) PAN/PS/CNP 0.1 Foam; (C) PAN/PS/CNP 0.3 Foam; (D) PAN/PS/CNP 1 Foam; and (E) PAN/PS/CNP 3 Foam

\section{Ion removal}

Time-dependent amount $\left(\mathrm{q}_{\mathrm{t}}\right)$ of $\mathrm{Pb}^{2+}$ ions removed by PAN/PS/CNP 0.3 Foam and PAN/PS/CNP 3 Foam from aqueous solution is shown in Fig. 9. The Eq. 2 was used to calculate $\mathrm{q}_{\mathrm{t}}(\mathrm{mg} / \mathrm{g})$ for $\mathrm{Pb}^{2+}$ ions:

$$
\mathrm{q}_{\mathrm{t}}=\frac{\left(\mathrm{C}_{0}-\frac{\mathrm{C}) \mathrm{V}}{\mathrm{B}}\right.}{\mathrm{B}}
$$

Where $\mathrm{C}_{0}=$ initial $\mathrm{Pb}^{2+}$ ion concentration $(\mathrm{mg} / \mathrm{l}) ; \mathrm{C}=$ residual $\mathrm{Pb}^{2+}$ ion concentration $(\mathrm{mg} / \mathrm{l}) ; \mathrm{V}=$ volume of solution (1); and $\mathrm{B}=$ weight of nanocomposite foam $(\mathrm{g})$. The initial $\mathrm{Pb}^{2+}$ ion 
concentration was $100 \mathrm{mg} / \mathrm{L}$ at $\mathrm{pH}$ 3. The removal efficiency of foams was also calculated using Eq. 3:

$$
\text { Removal efficiency }(\%)=\underline{\mathrm{C}_{0}} \underline{\underline{\mathrm{C}}} \underline{\mathrm{C}}
$$

Table 3 shows $\mathrm{Pb}^{2+}$ ions removal efficiency. It was found that the nanofiller content directly influenced the $\mathrm{q}_{\mathrm{t}}$ and removal efficiency of $\mathrm{Pb}^{2+}$ ions from aqueous solution. The amount of $\mathrm{Pb}^{2+}$ ions removed by $3 \mathrm{wt} . \%$ nanofiller foam was much higher relative to $0.3 \mathrm{wt} . \%$ foam sample. Higher nanofiller loading offered better adsorption sites for $\mathrm{Pb}^{2+}$ ions. Up to $30 \mathrm{~h}$, there was continuous increase in $\mathrm{q}_{\mathrm{t}}$ of $\mathrm{Pb}^{2+}$ ions due to homogenous adsorption and distribution of adsorption sites. From 40-50h, there was slight decrease in the ion adsorption owing to hindrance of active sites with the adsorbed ions. As the time passes, the ion adsorption was again increased owing to the accumulation of active sites for ion removal. Consequently, prolonged exposure of foams to metal ions enhanced the removal capacity. Consequently, PAN/PS/CNP 3 Foam revealed removal capacity of $166 \mathrm{mg} / \mathrm{g}$ and removal efficiency of $99 \%$. The results depict positive impact of CNP on the removal of toxic metal ion.



Fig. 9. Time-dependent amount (qt) of Pb2+ ions removed by (A) PAN/PS/CNP 0.3 Foam and (B) PAN/PS/CNP 3 Foam in aqueous solutions with initial $\mathrm{Pb} 2+$ ion concentration of $100 \mathrm{mg} / \mathrm{L}$ at $\mathrm{pH} 3$

Testing of experimental results were also performed by adsorption isotherm method. According to Redlich-Petersen isotherm (Eq. 2):

$$
f=K c e M /\left(1+(K c e)^{\beta}\right)
$$

$f=$ ionic species sorbed per gram of material $\left(\mathrm{mmol} \mathrm{g}^{-1}\right)$; ce $=$ equilibrium concentration of ions $\left(\mathrm{mmol} \mathrm{l}^{-1}\right) ; \mathrm{M}=$ maximum adsorption $\left(\mathrm{mmol} \mathrm{g}^{-1}\right) ; \beta=$ degree of heterogeneity; $\mathrm{K}=$ constant. Fig. 10 graphically shows isotherm and curve of adsorption model approached. The isotherm has shown changes in surface sorption properties during ion binding. The Redlich-Petersen curve gave much better fit at higher concentrations of $\mathrm{Pb}$. It was found that the ionic species bind with the most favorable sites for multi-layer adsorption [36]. The adsorption isotherm of PAN/PS/CNP 3 Foam 
revealed better removal of species owing to appropriate adsorption sites on the nanocomposite surface. The effect of metal ion removal was found similar to the removal efficiency of the reported nanocarbon nanocomposite [37-39].

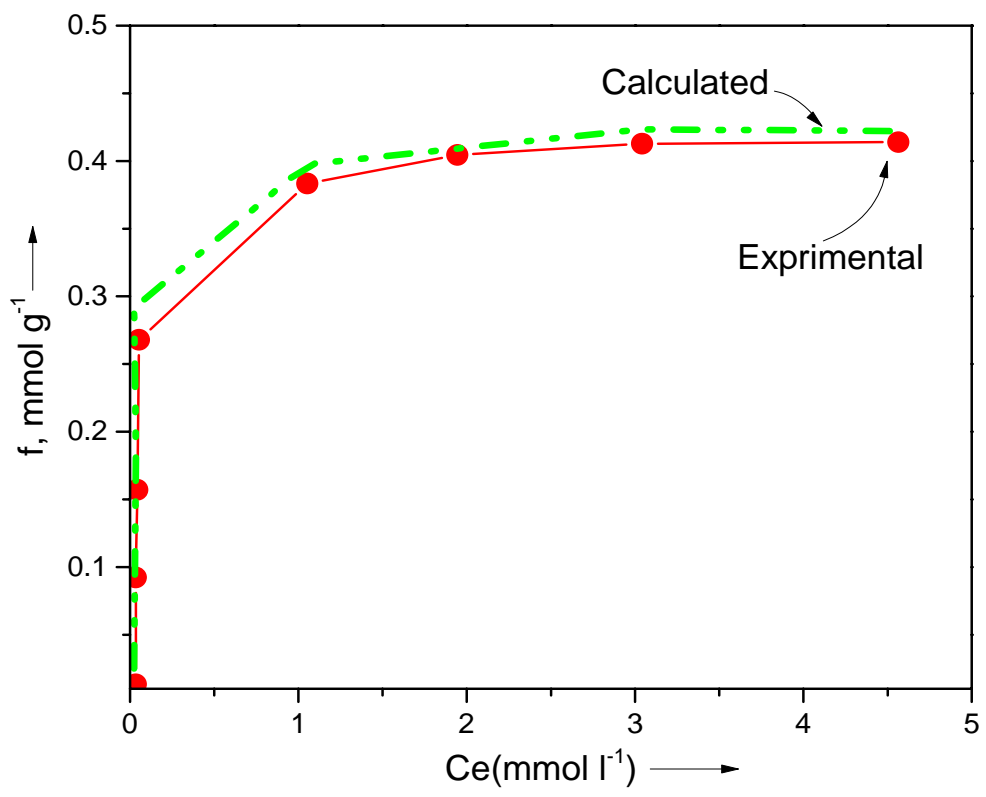

Fig. 10. Adsorption isotherms of $\mathrm{Pb} 2+$ ions for PAN/PS/CNP 3 Foam

CONCLUSIONS

Novel polyacrylonitrile/polystyrene/carbon nanoparticle-based foams were designed, fabricated, and investigated using FTIR, FESEM, TEM, TGA, UL94, compression tests, water absorption, and toxic ion removal. FTIR and microscopic studies have shown that the carbon nanoparticle nanoparticles were successfully incorporated and dispersed in the blend matrix through physical interaction. Among nano-cellular foams, $3 \mathrm{wt} \%$ CNP loading had unique nanocellular morphological pattern, high foam density, and compressive mechanical properties. High heat stability and flame resistance were also observed via superior thermal properties, char yield, and V-0 rating. In addition, the nanocomposite foam with high CNP content showed fine moisture uptake and $\mathrm{Pb}^{2+}$ ions removal capacity/efficiency. Thus, the cautiously designed blend structure and functional nanofiller led to the development of high performance strengthened and heat and flame retardant nanocellular foams for metal ion removal.

\section{REFERENCES}

1. Partovi-Azar, P., Jand, S.P., Kaghazchi, P.: Electronic, Magnetic, and Transport Properties of Polyacrylonitrile-Based Carbon Nanofibers of Various Widths: Density-Functional Theory Calculations. Physical Review Applied 9 (2018) 014012. 
2. Nataraj, S.K., Yang, K.S., Aminabhavi, T.M.: Polyacrylonitrile-based nanofibers-A state-of-the-art review. Progress in Polymer Science 37(2012) 487-513.

3. Bayramoğlu, G., Metin, A.Ü., Arıca, M.Y.: Surface modification of polyacrylonitrile film by anchoring conductive polyaniline and determination of uricase adsorption capacity and activity. Applied Surface Science 256 (2010) 6710-6716.

4. Li, P., Wang, Z., Yang, L., Zhao, S., Song, P., Khan, B.: A novel loose-NF membrane based on the phosphorylation and cross-linking of polyethyleneimine layer on porous PAN UF membranes. Journal of Membrane Science 555 (2018) 56-68.

5. Kausar, A., Ullah, W., Muhammad, B., Siddiq, M.: Novel mechanically stable, heat resistant and nonflammable functionalized polystyrene/expanded graphite nanocomposites. Advances in Materials Science 14 (2014) 61-74.

6. Tuli, S.K., Roy, A.L., Elgammal, R.A., Tian, M., Zawodzinski, T.A., Fujiwara, T.: Effect of Morphology on Anion Conductive Properties in Self-Assembled Polystyrene-Based Copolymer Membranes. Journal of Membrane Science 565 (2018) 213-225

7. Karanikas, S., Economou, I.G.: Molecular simulation of structure, thermodynamic and transport properties of polyacrylonitrile, polystyrene and their alternating copolymers in high temperatures. European Polymer Journal 47 (2011) 735-745.

8. Yang, Y., Daniels, E.S., Klein, A.: Synthesis of polyacrylonitrile/polystyrene latex particles that contain platinum. Journal of Applied Polymer Science 132 (2015).

9. Kim, Y., Kim, S., Noh, S., Kim, S., Park, G., Le, T.H., Han, H., Kim, Y.A., Yoon, H.: Single-Walled Carbon Nanotube-Mediated Physical Gelation of Binary Polymer Blends: An Efficient Route to Versatile Porous Carbon Electrode Materials. Chemical Engineering Journal 353 (2018) 849-857

10. Zhang, H., Quan, L., Shi, F., Li, C., Liu, H., Xu, L.: Rheological Behavior of Amino-Functionalized Multi-Walled Carbon Nanotube/Polyacrylonitrile Concentrated Solutions and Crystal Structure of Composite Fibers. Polymers 10 (2018) 186.

11. Chen, Y., Wang, Y., Zhang, H.B., Li, X., Gui, C.X., Yu, Z.Z.: Enhanced electromagnetic interference shielding efficiency of polystyrene/graphene composites with magnetic $\mathrm{Fe}_{3} \mathrm{O}_{4}$ nanoparticles. Carbon 82 (2015) 67-76.

12. Min, Z., Yang, H., Chen, F., Kuang, T.: Scale-up production of lightweight high-strength polystyrene/carbonaceous filler composite foams with high-performance electromagnetic interference shielding. Materials Letters 230 (2018) 157-160.

13. Wang, C., Xue, T., Dong, B., Wang, Z., Li, H.L.: Polystyrene-acrylonitrile-CNTs nanocomposites preparations and tribological behavior research. Wear 265 (2008) 1923-1926.

14. Wu, J., An, A.K., Guo, J., Lee, E.J., Farid, M.U., Jeong, S.: 2017. CNTs reinforced superhydrophobic-oleophilic electrospun polystyrene oil sorbent for enhanced sorption capacity and reusability. Chemical Engineering Journal 314 (2017) 526-536.

15. Echegoyen, L., Ortiz, A., Chaur, M.N., Palkar, A.J.: Carbon Nano Onions. Chemistry of Nanocarbons (2010) 463-483.

16. Bartolome, J.P., Fragoso, A.: Preparation of stable aqueous dispersions of carbon nano-onions via supramolecular crown ether-ammonium interactions with aminated biocompatible polymers. Journal of Molecular Liquids 269 (2018) 905-911.

17. Kausar, A.: Carbon nano onion as versatile contender in polymer compositing and advance application. Fullerenes, Nanotubes and Carbon Nanostructures 25 (2017) 109-123. 
18. Peled, E., Menachem, C., Bar Tow, D., Melman, A.: Improved Graphite Anode for Lithium Ion Batteries Chemically Bonded Solid Electrolyte Interface and Nanochannel Formation. Journal of The Electrochemical Society 143 (1996) L4-L7.

19. Ye, S., Vijh, A.K.: A New Fuel Cell Electrocatalyst Based on Carbonized Polyacrylonitrile Foam The Nature of Platinum Support Interactions. Journal of the Electrochemical Society 144 (1997) 9095.

20. Wang, J., Luo, C., Qi, G., Pan, K., Cao, B.: Mechanism study of selective heavy metal ion removal with polypyrrole-functionalized polyacrylonitrile nanofiber mats. Applied Surface Science 316 (2014) 245-250.

21. Bartelmess, J., Giordani, S.: Carbon nano-onions (multi-layer fullerenes): chemistry and applications. Beilstein Journal of Nanotechnology 5 (2014) 1980.

22. Yang, Y., Daniels, E.S., Klein, A.: Synthesis of polyacrylonitrile/polystyrene latex particles that contain platinum. Journal of Applied Polymer Science 132 (2015).

23. Kausar, A.: Polyurethane/Poly(2-chloro-5-methoxyaniline) and carbon nano-onion-based nanocomposite: physical properties and anti-corrosion behavior. Materials Research Innovations (2018) 1-9.

24. Kausar, A.: Polyimide, polybenzimidazole-in situ-polyaniline nanoparticle and carbon nano-onionbased nanocomposite designed for corrosion protection. International Journal of Polymer Analysis and Characterization 22 (2017) 557-567.

25. Kausar, A.: Effect of nanofiller dispersion on morphology, mechanical and conducting properties of electroactive shape memory Poly (urethane-urea)/functional nanodiamond composite. Advances in Materials Science 15 (2015) 14-28.

26. Kausar, A.: Polycarbonate/Polypropylene-Graft-Maleic Anhydride and Nano-Zeolite-Based Nanocomposite Membrane: Mechanical and Gas Separation Performance. Advances in Materials Science 16 (2016) 17-28.

27. Shen, B., Li, Y., Zhai, W., Zheng, W.: Compressible graphene-coated polymer foams with ultralow density for adjustable electromagnetic interference (EMI) shielding. ACS Applied Materials \& Interfaces 8 (2016) 8050-8057.

28. Kuang, T., Chang, L., Chen, F., Sheng, Y., Fu, D., Peng, X.: Facile preparation of lightweight highstrength biodegradable polymer/multi-walled carbon nanotubes nanocomposite foams for electromagnetic interference shielding. Carbon 105 (2016) 305-313.

29. Cai, Y., Wang, Q., Wei, Q., You, Q., Huang, F., Song, L., Hu, Y., Gao, W.: Structure, thermal, and antibacterial properties of polyacrylonitrile/ferric chloride nanocomposite fibers by electrospinning. International Journal of Polymer Analysis and Characterization 15(2010) 110-118.

30. Beyli, P.T., Doğan, M., Gündüz, Z., Alkan, M. and Turhan, Y.: Synthesis, Characterization and Their Antimicrobial Activities of Boron Oxide/Poly (Acrylic Acid) Nanocomposites: Thermal and Antimicrobial Properties. Advances in Materials Science 18(2018), 28-36.

31. Kausar, A.: Polyamide 1010/Polythioamide Blend Reinforced with Graphene Nanoplatelet for Automotive Part Application. Advances in Materials Science 17(2017) 24-36

32. Rettenbacher, A.S., Perpall, M.W., Echegoyen, L., Hudson, J., Smith, D.W.: Radical addition of a conjugated polymer to multilayer fullerenes (carbon nano-onions). Chemistry of Materials 19 (2007) 1411-1417. 
33. Zhao, J., Ren, W., Cheng, H.M.: Graphene sponge for efficient and repeatable adsorption and desorption of water contaminations. Journal of Materials Chemistry 22 (2012) 20197-20202.

34. Landowski, M., Budzik, M., Imielińska, K.: Water absorption and blistering of glass fibre-reinforced polymer marine laminates with nanoparticle-modified coatings. Journal of Composite Materials 48 (2014), 2805-2813.

35. Kizilduman, B.K., Alkan, M., Doğan, M., Turhan, Y.: Al-Pillared-Montmorillonite (AlPMt)/Poly (Methyl Methacrylate)(PMMA) Nanocomposites: The Effects of Solvent Types and Synthesis Methods. Advances in Materials Science 17 (2017) 5-23.

36. Perić, J., Trgo, M. and Medvidović, N.V.: Removal of zinc, copper and lead by natural zeolite-a comparison of adsorption isotherms. Water Research 38(2004) 1893-1899.

37. Musico, Y.L.F., Santos, C.M., Dalida, M.L.P., Rodrigues, D.F.: Improved removal of lead (II) from water using a polymer-based graphene oxide nanocomposite. Journal of Materials Chemistry A 1 (2013) 3789-3796.

38. Pyrzyńska, K., Bystrzejewski, M.: Comparative study of heavy metal ions sorption onto activated carbon, carbon nanotubes, and carbon-encapsulated magnetic nanoparticles. Colloids and Surfaces A: Physicochemical and Engineering Aspects 362 (2010) 102-109.

39. Zhao, X., Jia, Q., Song, N., Zhou, W., Li, Y.: Adsorption of Pb (II) from an aqueous solution by titanium dioxide/carbon nanotube nanocomposites: kinetics, thermodynamics, and isotherms. Journal of Chemical \& Engineering Data 55 (2010) 4428-4433. 